\title{
Gender differences in symptoms experienced by advanced cancer patients: a literature review
}

Erin Wong BSc ${ }^{1}$, Gillian Bedard BSc ${ }^{1}$, Natalie Pulenzas BSc ${ }^{1}$, Breanne Lechner BSc ${ }^{1}$, Henry Lam MLS ${ }^{2}$, Nemica Thavarajah BSc ${ }^{1}$, Lori Holden MRTT ${ }^{2}$, Edward Chow MBBS ${ }^{2}$, Natalie Lauzon MRTT ${ }^{2}$

Sunnybrook Health Sciences Centre, University of Toronto, Toronto, Ontario, Canada

2 Department of Radiation Therapy, Odette Cancer Centre, Sunnybrook Health Sciences Centre, Toronto, Ontario, Canada

\section{Abstract}

INTRODUCTION: Advanced cancer patients are multi-symptomatic and require attentive palliative care. As gender differences are apparent in multiple aspects of everyday life, this literature review aims to determine the gender differences seen in the population of advanced cancer patients and the symptoms that they experience.

METHODS: A literature review was conducted using the OvidSP Medline database from 1946 to November 2012. Randomized, prospective or retrospective cohort studies on advanced cancer patients who were undergoing any type of palliative treatments (palliative radiation, chemotherapy) or those in which palliative treatments have failed (antalgic treatment) were included. The patient population, tools/questionnaire used and gender differences in symptoms found statistically or qualitatively significant in the respective studies were extracted.

RESULTS: Of the 163 studies resulting from the literature search, nineteen publications were identified. Gender differences in multiple symptoms were discovered. Gender differences were commonly found in symptoms of emotional changes, fatigue, gastrointestinal symptoms (nausea, vomiting, and diarrhea) anxiety, tension, sleep problems and pain.

CONCLUSION: At present, gender differences seen in the symptoms experienced by advanced cancer patients continues to be inconclusive. Further study investigating gender differences in the symptoms experienced by advanced cancer patients as the primary endpoint is recommended.

\section{Keywords}

Gender differences; Advanced cancer; Palliative care 


\section{Introduction}

According to the World Health Organization, the main goal of palliative care is to improve the quality of life in patients and their family members when faced with a life-threatening illness [1]. Palliative care provides relief from pain or other stressful symptoms without pursuing change in the prognosis of the patient. It encompasses all aspects of patient care including physical, spiritual and psychological [1]. Therefore in palliative care for advanced cancer patients, symptom experience is of upmost importance as its affect on the quality of life of patients directs the palliative treatment decisions [2,3]. Advanced cancer patients are patients treated with a palliative intent and are usually described as being multi-symptomatic $[3,4]$. In this cancer population, inadequate symptom management is frequently reported due to multiple factors such as physician's under-estimation, inadequate assessment and patient's reluctance to report symptoms such as pain [5]. As such, understanding the factors that may influence the symptoms experienced by patients may assist palliative care physicians in better management of quality of life.

Gender appears to impact many elements of human nature, thus it is not unreasonable to hypothesize that there may be gender differences in oncology, specifically the symptoms experienced by palliative care cancer patients [6-9]. Studies specifically on gender differences in oncology symptoms have been rare [9]. The purpose of this review is to identify reported gender differences in symptoms experienced by palliative care cancer patients.

\section{Methods}

\section{Search strategy}

A literature review was conducted using the OvidSP Medline database from 1946 to November 2012. Subject headings and keywords 'palliative care' and 'terminal care' were combined with 'neoplasms'. This search was then combined with 'sex factors' or identified as having the terms 'gender' or 'sex' within three words of the term 'difference'.

There were 163 resultant articles identified. Three authors (EW, NL, and GB) independently identified potential articles. Articles were selected based upon title and abstract and relevant articles were pulled for further examination. References of the articles were manually searched for relevant publications.

\section{Inclusion criteria}

To be included in this present literature review, articles had to meet the following criteria:

- Population: patients diagnosed with advanced cancer.

- Intervention: treatments which were defined as being palliative in nature, including conventional palliative chemotherapy and radiation as well as treatments such as antalgic treatments for patients in which the conventional management has failed.

- Types of studies: randomized trials, prospective or retrospective cohort studies.

- Endpoint: gender difference as an area of investigation and a difference was found through analysis.

\section{Exclusion criteria}

Articles were excluded if any of the following criteria was met:

- Population: primary caregivers as the population of interest, populations in which patients could not be separated for analysis or population of interest which was focused on a single primary cancer site.

- Language: publications in a language other than English.

- Intervention: if within the population of study, any intervention that was deemed curative in nature. 
- Types of studies: review articles or case reports.

- Endpoint: gender difference was not an area of investigation or gender difference was not found significant after analysis.

Figure 1 illustrates the flow chart of article selection.

\section{Data extraction}

The following information was extracted from the identified publications:

- Sample size of the population.

- Patient population characteristics.

- Questionnaire/tool used to assess the symptoms.

- Gender differences observed in symptoms.

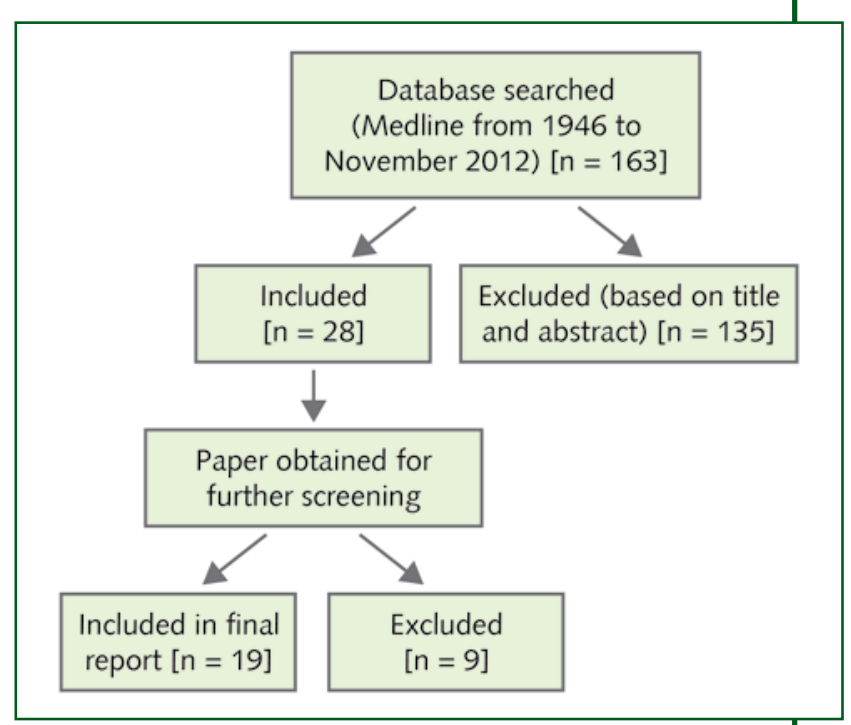

Figure 1. Flow chart of article selection

\section{Results}

Nineteen studies which indicated gender differences in symptoms experienced by palliative cancer patients were included in this review. Flow chart of article selection is illustrated in Figure 1. A variety of symptoms were identified which exhibited differences based on the gender of the patient. The resultant symptoms included: emotions, fatigue, sleep problems, nausea, vomiting, anxiety, hoarseness, early satiety, pain and others (Table I).

\begin{tabular}{|c|c|c|c|c|}
\hline Reference & $\begin{array}{l}\text { Sample } \\
\text { size (n.) }\end{array}$ & Patient population & $\begin{array}{c}\text { Questionnaire/tool } \\
\text { used }\end{array}$ & Gender difference \\
\hline \multicolumn{5}{|c|}{ Symptom identified: dyspnea } \\
\hline $\begin{array}{l}\text { Heedman } \\
\text { et al. [24] }\end{array}$ & 431 & $\begin{array}{l}\text { Patients with metastatic } \\
\text { diseases admitted to a } \\
\text { hospital-based home care } \\
\text { due to need of palliative } \\
\text { care were recruited }\end{array}$ & $\begin{array}{l}\text { Edmonton Symptom } \\
\text { Assessment System } \\
\text { (ESAS) and a visual } \\
\text { analog scale assessing } \\
\text { overall quality of life }\end{array}$ & $\begin{array}{l}\text { Dyspnea was the only gender-different } \\
\text { symptom found; male patients had greater } \\
\text { dyspnea than female patients }\end{array}$ \\
\hline \multicolumn{5}{|c|}{ Symptom identified: emotions } \\
\hline $\begin{array}{l}\text { Carey et al. } \\
{[10]}\end{array}$ & 172 & $\begin{array}{l}\text { Terminally ill advanced } \\
\text { cancer patients treated in a } \\
\text { cancer center with or with- } \\
\text { out holistic care (main focus } \\
\text { of study) }\end{array}$ & $\begin{array}{l}\text { Profile of Mood States } \\
\text { (POMS) }\end{array}$ & $\begin{array}{l}\text { Female patients self-described themselves as } \\
\text { being in more positive moods than males (on } \\
\text { all } 6 \text { POMS scale). Female patients were less } \\
\text { tense, less anxious and less fatigued }\end{array}$ \\
\hline \multirow[t]{2}{*}{$\begin{array}{l}\text { Zimmerman } \\
\text { et al. [11] }\end{array}$} & 285 & $\begin{array}{l}\text { Patients with advanced } \\
\text { cancer (diagnosed with } \\
\text { Stage IV cancer, stage III/ } \\
\text { IV lung cancer, and locally } \\
\text { advanced pancreatic or } \\
\text { esophageal cancer) and } \\
\text { had a clinical prognosis of } 6 \\
\text { months to } 2 \text { years }\end{array}$ & $\begin{array}{l}\text { Functional Assessment } \\
\text { of Cancer Therapy - } \\
\text { General (FACT-G) and } \\
\text { Functional Assessment } \\
\text { of Chronic Illness Ther- } \\
\text { apy - Spiritual Well- } \\
\text { being (FACIT-Sp) }\end{array}$ & $\begin{array}{l}\text { Male patients had better emotional well- } \\
\text { being in comparison to female patients; } \\
\text { therefore male gender was predicted to have } \\
\text { better emotional well-being }\end{array}$ \\
\hline & & & & Continues > \\
\hline \multicolumn{4}{|c|}{ (C) SEEd All rights reserved } & Reviews in Health Care $2013 ; 4(2)$ \\
\hline
\end{tabular}


$>$ Follows

\begin{tabular}{|c|c|c|c|c|}
\hline Reference & $\begin{array}{l}\text { Sample } \\
\text { size (n.) }\end{array}$ & Patient population & $\begin{array}{c}\text { Questionnaire/tool } \\
\text { used }\end{array}$ & Gender difference \\
\hline \multicolumn{5}{|c|}{ Symptom identified: emotions in relation to pain } \\
\hline $\begin{array}{l}\text { Sela et al. } \\
\text { [12] }\end{array}$ & 111 & $\begin{array}{l}\text { Advanced cancer } \\
\text { outpatients were recruited } \\
\text { from a Pain and Symptom } \\
\text { Control Clinic. Patients with } \\
\text { a diagnosis of cancer, no } \\
\text { brain metastases and had a } \\
\text { mini mental score of } 28 / 30 \\
\text { or more were eligible for } \\
\text { inclusion }\end{array}$ & $\begin{array}{l}\text { A Pain and Symptom } \\
\text { Control Clinic } \\
\text { Assessment form, which } \\
\text { consisted of seven } \\
\text { visual analogue scales, } \\
\text { was used to measure } \\
\text { the two dimensions of } \\
\text { cancer pain: sensation/ } \\
\text { intensity and affect }\end{array}$ & $\begin{array}{l}\text { Gender difference was seen between the } \\
\text { emotions associated with pain. Females } \\
\text { experienced statistically significant emotions } \\
\text { of fear and hopelessness in relations to } \\
\text { cancer pain compared to males. } \\
\text { There was also a gender difference } \\
\text { in emotional reactions towards the } \\
\text { physical sensory dimension of pain: } \\
\text { males experienced frustration, anger, and } \\
\text { exhaustion while females experienced } \\
\text { frustration, helplessness and exhaustion. } \\
\text { Male patients reported feelings of } \\
\text { hopelessness and helplessness as } \\
\text { insignificant. } \\
\text { In relation to pain, correlations between } \\
\text { emotions were different for both genders. } \\
\text { Correlations were seen between 'anger and } \\
\text { frustration', 'hopelessness and helplessness,' } \\
\text { and 'anger and fear' in male patients while } \\
\text { 'helplessness and anger', 'hopelessness and } \\
\text { fear', and 'hopelessness and helplessness' } \\
\text { were seen in female patients }\end{array}$ \\
\hline
\end{tabular}

Symptom identified: fatigue

Zeng et al. 1,397 Advanced cancer patients [13] referred to the Rapid Re-
sponse Radiotherapy Pro-
gram for palliative radio-
therapy were recruited at
an outpatient cancer center

Symptom identified: nausea and symptom cluster

Cheung et 1,358 Patients aged 18 years al. [9] or older with metastatic cancer were recruited from the oncology palliative care clinics at a hospital in Toronto, Ontario, Canada

Edmonton Symptom Significant correlation was found between and Assessment System the female gender and fatigue (ESAS)

Edmonton Symptom Assessment System (ESAS)
Female patients reported poorer nausea scores than males.

The main symptom cluster for male patients was: pain, depression and anxiety. There was also a secondary cluster of fatigue, decreased appetite, and dyspnea. In females, the main symptom cluster was decreased appetite, pain, nausea, drowsiness and fatigue. There was also a secondary cluster of poor general well-being, depression, and anxiety

\section{Symptom identified: nausea and vomiting}

\begin{tabular}{|c|c|c|c|c|}
\hline $\begin{array}{l}\text { Reuben et } \\
\text { al. [17] }\end{array}$ & 1,596 & $\begin{array}{l}\text { Terminal cancer patients } \\
\text { with confirmed malignancy } \\
\text { and a medically certified } \\
\text { prognosis of } 6 \text { months or } \\
\text { less were recruited }\end{array}$ & $\begin{array}{l}\text { A modified set of ques- } \\
\text { tions from Melzak was } \\
\text { used to measure symp- } \\
\text { toms experienced by } \\
\text { patients }\end{array}$ & $\begin{array}{l}67 \% \text { of female patients reported } \\
\text { symptoms of nausea and vomiting in } \\
\text { comparison to the } 56 \% \text { of male patients } \\
\text { who reported symptoms of nausea } \\
\text { and vomiting. There was no correlating } \\
\text { explanation of this relationship with age, } \\
\text { chemotherapy or primary cancer site. This } \\
\text { relationship was still found significant } \\
\text { when breast cancer was excluded }\end{array}$ \\
\hline
\end{tabular}




\begin{tabular}{|c|c|c|c|c|}
\hline Reference & $\begin{array}{l}\text { Sample } \\
\text { size (n.) }\end{array}$ & Patient population & $\begin{array}{l}\text { Questionnaire/tool } \\
\text { used }\end{array}$ & Gender difference \\
\hline \multicolumn{5}{|c|}{ Symptom identified: pain } \\
\hline $\begin{array}{l}\text { Kanbayashi } \\
\text { et al. [21] }\end{array}$ & 71 & $\begin{array}{l}\text { Terminal cancer patients } \\
\text { with cancer pain were } \\
\text { recruited from a university } \\
\text { hospital }\end{array}$ & $\begin{array}{l}\text { States of pain were } \\
\text { evaluated using a } 5 \\
\text { point verbal rating scale } \\
\text { (0-excellent, 1-good, } \\
\text { 2-moderate, 3-poor, } \\
\text { and 4-very poor) }\end{array}$ & $\begin{array}{l}\text { Cancer pain was significantly correlated with } \\
\text { gender: cancer pain was worsened when the } \\
\text { patient was of the male gender }\end{array}$ \\
\hline $\begin{array}{l}\text { Mercadante } \\
\text { et al. [22] }\end{array}$ & 181 & $\begin{array}{l}\text { Advanced cancer patients } \\
\text { on opioid therapy for more } \\
\text { than } 4 \text { weeks prior to } \\
\text { death were included in the } \\
\text { study. These patients were } \\
\text { followed at home until } \\
\text { death }\end{array}$ & $\begin{array}{l}\text { Clinical information } \\
\text { was collected for each } \\
\text { patient: pain intensity } \\
\text { (either self-reported } \\
\text { or doctor-rated VAS), } \\
\text { symptoms associated } \\
\text { with opioid therapy, and } \\
\text { information regarding } \\
\text { opioid dosage were } \\
\text { recorded }\end{array}$ & $\begin{array}{l}\text { Female patients reported visceral pain more } \\
\text { frequently while male patients reported } \\
\text { somatic pain more frequently }\end{array}$ \\
\hline $\begin{array}{l}\text { Tu et al. } \\
\text { [23] }\end{array}$ & 58 & $\begin{array}{l}\text { Advanced cancer inpatients } \\
\text { and caregivers who were } \\
\text { able to complete a survey } \\
\text { (as judged by a health care } \\
\text { professional) were recruited }\end{array}$ & $\begin{array}{l}\text { Specialized } \\
\text { questionnaire that } \\
\text { included: demographic } \\
\text { data, disease } \\
\text { information, evaluation } \\
\text { of bio-psycho-social } \\
\text { factors and quality of life }\end{array}$ & $\begin{array}{l}\text { Pain perception was affected by gender. } \\
\text { Patients who were of the female gender } \\
\text { were more likely to have higher pain } \\
\text { perception }\end{array}$ \\
\hline \multicolumn{5}{|c|}{ Symptom identified: self-efficacy } \\
\hline $\begin{array}{l}\text { Mystakidou } \\
\text { et al. [25] }\end{array}$ & 99 & $\begin{array}{l}\text { Stage IV advanced cancer } \\
\text { patients were recruited } \\
\text { from the Pain Relief and } \\
\text { Palliative Care Unit }\end{array}$ & $\begin{array}{l}\text { Gender Self-Efficacy } \\
\text { Scale (GSE) and } \\
\text { Spielberger's State-Trait } \\
\text { Anxiety Inventory (STAI) }\end{array}$ & $\begin{array}{l}\text { Male patients experienced significantly more } \\
\text { self-efficacy than female patients }\end{array}$ \\
\hline \multicolumn{5}{|c|}{ Symptom identified: taste change and diarrhea } \\
\hline $\begin{array}{l}\text { Komurcu et } \\
\text { al. [20] }\end{array}$ & 50 & $\begin{array}{l}\text { Advanced cancer patients } \\
\text { admitted to the Cleveland } \\
\text { Clinic Foundation Palliative } \\
\text { Medicine Program were } \\
\text { recruited. Patients with } \\
\text { confirmed malignancy and } \\
\text { were not receiving chemo- } \\
\text { therapy or radiation were } \\
\text { eligible }\end{array}$ & $\begin{array}{l}\text { Survey consisting } \\
\text { of questions on } \\
\text { demographic } \\
\text { and medical } \\
\text { information as well } \\
\text { as } 16 \text { gastrointestinal } \\
\text { symptoms questions }\end{array}$ & $\begin{array}{l}\text { After the exclusion of gender-specific primary } \\
\text { cancer sites, there was no gender difference } \\
\text { in terms of number of gastrointestinal } \\
\text { symptoms experienced. However, female } \\
\text { patients experienced more taste change } \\
\text { and diarrhea in comparison to their male } \\
\text { counterpart and this remained significant } \\
\text { after the exclusion of gender-specific primary } \\
\text { cancer sites }\end{array}$ \\
\hline \multicolumn{5}{|c|}{ Symptom identified: variety } \\
\hline $\begin{array}{l}\text { Donnelly et } \\
\text { al. [3] }\end{array}$ & 1,000 & * & $\circ$ & $\begin{array}{l}\text { Male patients reported dyspnea and } \\
\text { hiccough more commonly than female } \\
\text { patients. } \\
\text { For } 8 \text { symptoms, gender difference in } \\
\text { severity was found. Symptoms of dyspnea, } \\
\text { hoarseness, hiccough and dysphagia were } \\
\text { more severe in males, while anxiety, nausea, } \\
\text { vomiting, and early satiety were more severe } \\
\text { in females }\end{array}$ \\
\hline
\end{tabular}


$>$ Follows

\begin{tabular}{|c|c|c|c|c|}
\hline Reference & $\begin{array}{l}\text { Sample } \\
\text { size (n.) }\end{array}$ & Patient population & $\begin{array}{l}\text { Questionnaire/tool } \\
\text { used }\end{array}$ & Gender difference \\
\hline $\begin{array}{l}\text { Dunlop et } \\
\text { al. [15] }\end{array}$ & 50 & $\begin{array}{l}\text { Patients with far advanced } \\
\text { cancer were recruited from } \\
\text { two hospices. These pa- } \\
\text { tients had to have had suf- } \\
\text { ficient orientation as judged } \\
\text { by the interviewer }\end{array}$ & $\begin{array}{l}\text { Cards with } 6 \text { relevant } \\
\text { symptoms and } 8 \text { other } \\
\text { symptoms were used. } \\
\text { The symptoms on the } \\
\text { card were chosen in } \\
\text { reference to the results } \\
\text { of a survey completed } \\
\text { in the advanced cancer } \\
\text { population. Patients } \\
\text { were also asked to vol- } \\
\text { unteer other symptoms } \\
\text { not listed on the cards }\end{array}$ & $\begin{array}{l}\text { In female patients, certain gastrointestinal } \\
\text { symptoms were more frequent and self-rated } \\
\text { as more distressing, this included: dry mouth } \\
\text { (twice as frequent and second most distress- } \\
\text { ing symptom) and nausea (twice as frequent } \\
\text { and fourth most distressing symptom). } \\
\text { For male patients, constipation and difficulty } \\
\text { sleeping occurred more frequently than in } \\
\text { female patients and was ranked higher as a } \\
\text { distressing symptom }\end{array}$ \\
\hline $\begin{array}{l}\text { Mercadante } \\
\text { et al. [19] }\end{array}$ & 211 & $\begin{array}{l}\text { Advanced cancer patients } \\
\text { referred to a home palliative } \\
\text { care program who survived } \\
\text { for more than } 3 \text { weeks } \\
\text { through retrospective as- } \\
\text { sessments were included. } \\
\text { Patients who were experi- } \\
\text { encing certain symptoms } \\
\text { were selected for inclusion }\end{array}$ & $\begin{array}{l}\text { Information on pain } \\
\text { intensity (self-reported } \\
\text { or doctor-rated VAS), } \\
\text { symptoms (due to opi- } \\
\text { oid usage or advanced } \\
\text { cancer), and informa- } \\
\text { tion regarding opioid } \\
\text { usage were collected }\end{array}$ & $\begin{array}{l}\text { Gender difference was found for nausea and } \\
\text { vomiting (at baseline and last visit before } \\
\text { death), dry mouth (at baseline and ten days } \\
\text { after treatment) and diarrhea (at ten days } \\
\text { after treatment and last visit before death). } \\
\text { Female patients more frequently reported all } \\
\text { four of these symptoms than male. } \\
\text { However, male patients more frequently re- } \\
\text { ported dyspnea at baseline than female }\end{array}$ \\
\hline $\begin{array}{l}\text { Mercadante } \\
\text { et al. [18] }\end{array}$ & 373 & $\begin{array}{l}\text { Advanced cancer patients } \\
\text { referred to a home pal- } \\
\text { liative care program were } \\
\text { included in this study and } \\
\text { followed until death. Pa- } \\
\text { tients who were experienc- } \\
\text { ing certain symptoms were } \\
\text { selected for inclusion }\end{array}$ & $\begin{array}{l}\text { Information on pain in- } \\
\text { tensity (self-reported or } \\
\text { doctor-rated VAS) and } \\
\text { symptoms (due to opi- } \\
\text { oid usage or advanced } \\
\text { cancer) were collected }\end{array}$ & $\begin{array}{l}\text { Nausea and vomiting was more common to } \\
\text { female patients at three respective perfor- } \\
\text { mance statuses (KPS } 50,40,10 \text { ), while diar- } \\
\text { rhea was more common to female patients } \\
\text { at KPS } 50 \text { and } 40 \text {. At performance status of } \\
\text { KPS } 10 \text {, female patients experienced greater } \\
\text { severity of confusion than male patients. } \\
\text { Greater severity of dyspnea was found in } \\
\text { male patients at KPS of } 50\end{array}$ \\
\hline $\begin{array}{l}\text { Kirkova et } \\
\text { al. [4] }\end{array}$ & 1,000 & $\begin{array}{l}\text { Both inpatients and out- } \\
\text { patients with a diagnosis } \\
\text { of cancer referred to a Pal- } \\
\text { liative Medicine Program } \\
\text { were recruited* }\end{array}$ & $\begin{array}{l}\text { An } 8 \text { page checklist } \\
\text { which included: } \\
\text { demographics, } \\
\text { diagnosis, ECOG } \\
\text { performance score, and } \\
\text { self-reported prevalence } \\
\text { and severity of } 38 \\
\text { empirically-chosen } \\
\text { symptoms (rated as } \\
\text { mild, moderate, or } \\
\text { severe in intensity) }\end{array}$ & $\begin{array}{l}\text { Male patients had a higher prevalence } \\
\text { of sleep problems than females. Nausea, } \\
\text { vomiting and anxiety were more prevalent in } \\
\text { female patients than their male counterpart. } \\
\text { In terms of interaction between demographic } \\
\text { factors: age, gender and performance status } \\
\text { (PS) were significantly associated with the } \\
\text { prevalence of anxiety. It was found that older } \\
\text { male patients with a lower PS presented with } \\
\text { more anxiety than younger female patients } \\
\text { with a higher PS }\end{array}$ \\
\hline $\begin{array}{l}\text { Walsh et al. } \\
\text { [16] }\end{array}$ & 1,000 & $*$ & $\circ$ & $\begin{array}{l}\text { Gender was found to be associated with } 4 \\
\text { other symptoms: dysphagia, hoarseness, } \\
>10 \% \text { weight loss, and early satiety. } \\
\text { Symptoms of dysphagia, hoarseness, }>10 \% \\
\text { weight loss were more likely to occur in } \\
\text { male patients. However, early satiety was } \\
\text { more likely to occur in female patients. } \\
\text { After excluding gender-specific primary } \\
\text { cancer sites (ovary, uterus, breast, cervix and } \\
\text { prostate) a difference in results was found. } \\
\text { Male patients were now associated with } \\
\text { more coughing and headaches than females } \\
\text { while the association between male gender } \\
\text { and sleep problems disappeared }\end{array}$ \\
\hline
\end{tabular}




\begin{tabular}{|c|c|c|c|c|}
\hline Reference & $\begin{array}{l}\text { Sample } \\
\text { size (n.) }\end{array}$ & Patient population & $\begin{array}{c}\text { Questionnaire/tool } \\
\text { used }\end{array}$ & Gender difference \\
\hline $\begin{array}{l}\text { Zimmerman } \\
\text { et al. [14] }\end{array}$ & 150 & $\begin{array}{l}\text { Patients referred to the } \\
\text { palliative care clinic in To- } \\
\text { ronto, Ontario, Canada } \\
\text { were recruited if they had } \\
\text { metastatic cancer and were } \\
18 \text { years of age or older, } \\
\text { able to provide consent and } \\
\text { were able to complete the } \\
\text { questionnaire }\end{array}$ & $\begin{array}{l}\text { Edmonton Symptom } \\
\text { Assessment System } \\
\text { (ESAS) }\end{array}$ & $\begin{array}{l}\text { Greatest gender difference was found for the } \\
\text { symptoms: anxiety and appetite. Female pa- } \\
\text { tients experienced greater anxiety than male } \\
\text { patients. Female patients also had less appe- } \\
\text { tite in comparison to their male counterparts. } \\
\text { Gender differences were also found for the } \\
\text { symptoms: depression, fatigue, sense of } \\
\text { well-being and drowsiness. Female patients } \\
\text { scored worse on these symptoms than male } \\
\text { patients }\end{array}$ \\
\hline
\end{tabular}

Table I. Summary of gender differences found in the 19 studies

* Same patient population as previously mentioned

- Same questionnaire/tool used as previously mentioned

\section{Findings}

Gender difference in emotions, or changes in emotions, caused by advanced cancer was analyzed by multiple studies and found to be significant [10-12]. Carey et al. found that terminally ill female cancer patients were in more positive moods [10]. However, a contradicting discovery was made by Zimmerman et al. who found that male advanced cancer patients tended to have better emotional well-being than their female counterparts [11]. Another study by Sela et al. investigated emotions elicited in response to cancer pain and found that there was a difference between emotions experienced by male and female patients. Both males and females experienced similar frustration and exhaustion, however a significant difference was found between the amounts of helplessness experienced, with females experiencing greater helplessness [12].

Gender differences were also observed in symptoms of fatigue [10,13,14]. Carey et al. reported that terminally ill female cancer patients were less fatigued than their male counterparts [10]. However, Zeng et al. found contrasting evidence in a population of advanced cancer patients referred for palliative radiotherapy, in which female patients experienced more fatigue than male patients [13]. Similar findings were seen in the study by Zimmerman et al., in which female patients also had more fatigue than male patients [14].

Tension and anxiety were also two symptoms found to exhibit a gender difference [10]. Carey et al. found that terminally ill female cancer patients were both less tense and less anxious than male patients however three other studies have found the contrary [10]. In terms of sleep problems experienced by patients, Kirkova et al. and Dunlop et al. both found that advanced cancer male patients had significantly more sleep problems than female patients [4,15]. Similarly, Walsh et al. found the same relationship, however after gender-specific primary cancers were excluded from analysis, the relationship between the male gender and sleep problem did not remain significant [16].

Nausea, vomiting and diarrhea were also symptoms where gender differences were observed [4,9,15,1720]. Throughout the studies that examined nausea and vomiting in relation to gender, all studies concluded that these two symptoms occurred more frequently in female advanced cancer patients [4,9,15,17-19]. Donnelly et al. also found that female gender was associated with greater severity of these symptoms [3]. Similarly, females reported more diarrhea than male patients, while Dunlop et al. found that male patients experienced constipation more frequently than females and it was also greatly distressing to these patients [18-20]. Pain was also a significant symptom in which gender difference was found [21-23]. Kanbayashi et al. found that cancer pain was more severe if the advanced cancer 
patients were of the male gender [21]. However, contradictory findings were found by Tu et al. who found that female advanced cancer patients experienced higher pain perception than male patients [23]. Mercadante et al. also found that there was a gender difference in terms of the type of pain experienced by each gender. Female advanced cancer patients experienced more visceral pain while male patients reported more somatic pain [22].

Walsh et al. and Donnelly et al. found a gender difference associated with the symptoms of dysphagia and hoarseness with males experiencing these symptoms more commonly and with greater severity than females [3,16]. Walsh et al. also found that male patients experienced greater than $10 \%$ weight loss more commonly than females, however Donnelly et al. found that females experienced greater severity of early satiety $[3,16]$. The gender difference seen in the symptom of early satiety was further confirmed by Zimmerman et al. who also found that female patients experienced greater decreased appetite in comparison with male patients [14]. When gender-specific primary cancer sites were excluded from the study by Walsh et al., male gender was also associated with coughing and headaches while female gender was associated with symptoms of early satiety [16].

Three studies concluded that male patients experienced dyspnea more commonly with one study reporting males experiencing greater severity of it as well $[3,19,24]$. Mercadante et al. more specifically found that male patients suffered greater severity of dyspnea at Karnofsy Performance Score (KPS) of $50[18]$.

There were other symptoms that were not as commonly investigated. Mystakidou et al. conducted the only study that looked at self-efficacy gender differences. Self-efficacy is the judgment of one's own ability to mentally and physically execute a task. It is also associated with psychological health with efficacious people more prone to positivity while others with lower self-efficacy more prone to negativity or depression [25]. It was found that male patients experienced greater self-efficacy than female patients [25]. Komurcu et al. found that taste change occurred more commonly in female patients while Mercadante et al. and Dunlop et al. found that dry mouth occurred more frequently in female patients $[15,19,20]$. A study by Mercadante et al. also found that greater severity of confusion occurred in female patients with a KPS of 10 [22]. Zimmerman et al. found that females experienced greater depression, more negative sense of well-being and greater drowsiness than their male counterparts [14].

\section{Discussion}

Symptoms experienced by advanced cancer patients are of considerable importance as it determines the direction of their palliative care [1]. Gender influence is an important aspect of investigation in its relationship with symptom experience.

From the 19 included studies, multiple symptoms that were influenced by gender were identified including: emotion, pain, fatigue and many others. Although specific influences of a gender on emotions or changes in emotions experienced by advanced cancer patients was contradictory, there is strong evidence that in general, gender does influence the emotion of patients as demonstrated by Holzner et al. in a general population using the Fact-G $[10,11,26]$. This difference in the general population, however, was less pronounced than in the advanced cancer population identified by Zimmerman et al. $[11,26]$. Such gender differences in emotional moods within the advanced cancer patient population may be associated with psychological factors such as the denial of the diagnosis of advanced cancer [10]. Furthermore, as suggested by the gender differences seen in the emotional perception of pain, gender differences in emotions may be a confounding factor for other symptoms in which a gender difference is observed due to the emotional perception of the other symptoms [11,12]. This further promotes the complexity behind this symptom. Further research in this area is required to enable the 
promotion of individualized psychotherapy for patients with advanced cancer especially in hopes of further improving their emotional quality of life.

Similarly, gender difference on the symptom of fatigue was also inconclusive however, there have been other studies in a variety of populations that identified gender difference in the symptom of fatigue. Similar to the findings by Zeng et al., Pater et al., in a population of cancer patients (not only advanced cancer) found that more severe fatigue was associated with female cancer patients [27]. Husain et al. and Kroenke et al. also found that females have more fatigue in a palliative care population with patients of multiple advanced illnesses and adult primary-care patients respectively $[28,29]$. Similarly, Akechi et al. found that the symptom of fatigue was greater in ambulatory female cancer patients (not necessarily advanced cancer) [30]. In conjunction to this discovery, they also found that female patients who were housewives had less fatigue in comparison, suggesting this may be dependent on the burden of work as well [30]. As seen from the supporting studies, gender differences occur commonly for the symptom of fatigue, with females generally experiencing more fatigue than males. Cancer patients experience psychological distress such as tension and anxiety. Similar symptom pattern with respect to gender was seen in general cancer patients, not only palliative advanced cancer patients, which observed that females experienced significantly greater anxiety than males [31-33]. For symptoms such as fatigue, tension and anxiety, the greater prevalence seen in the female gender may also be accounted for, or at least partially, by the observation that females report a greater symptom burden [14].

Pain was also a symptom of controversy. The influence of gender on the types of pain experienced, as suggested by Mercadante et al., may explain the differences as they found that female patients experienced more visceral pain while male patients experienced more somatic pain [22]. As well, the emotions elicited by cancer pain may also affect the gender difference [12]. In a group of healthy individuals, Keogh et al. found that pain is exacerbated in females when they are unable to separate the sensation from the emotional feelings elicited by the pain [34]. Gender difference in the symptom of pain may also be explained by the differences in pain threshold between males and females. As demonstrated by Soetanto et al. and in accordance to previous studies, females presented with lower threshold for pain than males [35]. This difference in pain threshold may be a combination of biological and sociological manifestation. Greater awareness of pain in females may be due to their lifetime experience of greater biological pain from menstruation or childbirth, while a sociological manifestation may be the reason for fewer reports of pain by males due to their role expectations [36]. Due to these biological and sociological differences, females and males may report different pain severity despite experiencing the same amount of pain. As such, these findings suggest that health care professionals should take into consideration the multidimensionality of pain by combining emotional counseling with other treatments, especially for female patients.

For nausea and vomiting, although the increased frequency seen in females in the advanced cancer population is generally agreed upon and this prevalence is also common to other disorders, its' mechanism is still uncertain $[4,9,15,17-20]$. Symptoms such as dyspnea, decreased appetite, drowsiness, sleep problems, hoarseness, diarrhea, constipation and others were all found to have gender difference in experience. However, as there was not an overwhelming source of evidence, it would be advisable to conduct further investigation for such symptoms $[3,9,15,24]$.

A limitation of this study is that gender difference in symptom experience was not the primary endpoint of any of the studies included in this review. A second limitation is the heterogeneity of the tools used which in turn leads to difficulty in the comparison of results. Thirdly, the heterogeneity of the patient population may also explain certain differences in findings. An example of this limitation is seen in the difference in findings between Carey et al. and Zeng et al. on the symptom of fatigue. Even within the advanced cancer patient population, there is a spectrum of patients. The patient population in the study by Carey et al. only included terminally-ill advanced cancer patients, who were inpatients at a hospital, while the study by Zeng et al. included any outpatient advanced cancer patients with a larger 
variation on prognosis $[10,13]$. This may contribute to the differences in findings and may also explain other discrepancies between studies as terminally-ill inpatients have a lower performance status on average in comparison to the other advanced cancer patients $[4,10,11]$.

As shown in the study by Walsh et al., exclusion of gender-specific primary cancer types can also change the gender differences observed [16]. This suggests that primary cancer types significantly affect the symptoms experienced by advanced cancer patients and is also a limitation in this review as the gender differences may be influenced by the primary cancer types. Therefore for future studies on gender difference, these limitations should be addressed in order to determine conclusive evidence on the effects of gender on symptom experience in this subpopulation.

For the symptoms experienced by palliative cancer patients, gender differences identified may be due to difference in perception, reporting, or even actual biological differences between the two sexes $[11,36]$. As there is significant difference between males and females in other areas of health such as cardiovascular diseases or psychological diseases, gender difference should also be an important consideration in the treatment of patients with advanced cancer [37]. Additionally, the influence of gender should not only be considered for treatment of patients but also in the creation of health care policies and the design of clinical trials as it plays an important role in a patient's experience of certain symptoms and their palliation. It is suggested that symptoms identified in this review be further investigated with gender difference being the primary endpoint to discover the conclusive influence of gender. Furthermore, as gender differences are also seen in symptom experience of other non-cancer patients as well as the general population, it is worthwhile to investigate the differences in gender impact on symptoms of advanced cancer patients in comparison to other patient populations to better understand the implications [26,38-40].

\section{Question for further research}

It is suggested that symptoms identified in this review be further investigated with gender difference being the primary endpoint to discover the conclusive influence of gender

\section{The review in brief}

Clinical question Advanced cancer patients are multi-symptomatic and require attentive palliative care. As gender differences are apparent in multiple aspect of everyday life, this literature review aims to determine the gender differences seen in the population of advanced cancer patients and the symptoms that they experience.

Type of review Narrative

Search of $\quad$ A literature review was conducted using the OvidSP Medline database from 1946 to November 2012

literature Subject headings and keywords 'palliative care' and 'terminal care' were combined with 'neoplasms.' This search was then combined with 'sex factors' or identified as having the terms 'gender' or 'sex' within three words of the term 'difference.'

Conclusions At present, gender differences seen in the symptoms experienced by advanced cancer patients continues to be inconclusive.

Limitations Primary cancer types significantly affect the symptoms experienced by advanced cancer patients and is a limitation in this review as the gender differences may be influenced by the primary cancer types. 


\section{Acknowledgements}

We thank the generous support of the Bratty Family Fund, Michael and Karyn Goldstein Cancer Research Fund, Joseph and Silvana Melara Cancer Research Fund, and the Ofelia Cancer Research Fund.

\section{References}

1. World HO. WHO Definition of Palliative Care. 2012. Available at: http://www.who.int/cancer/palliative/definition/en/. Last accessed December 2012

2. Walsh D, Rybicki L, Nelson KA, et al. Symptoms and prognosis in advanced cancer. Support Care Cancer 2002; 10: 385-8; http://dx.doi.org/10.1007/s00520-001-0318-z

3. Donnelly S, Walsh D. The symptoms of advanced cancer. Semin Oncol 1995; 22(2 Suppl 3): 67-72

4. Kirkova J, Rybicki L, Walsh D, et al. Symptom prevalence in advanced cancer: age, gender, and performance status interactions. Am J Hosp Palliat Care 2012; 29: 139-45; http://dx.doi. org/10.1177/1049909111410965

5. Cleeland CS. The measurement of pain from metastatic bone disease: capturing the patient's experience. Clin Cancer Res 2006; 12: 6236s-42s; http://dx.doi.org/10.1158/1078-0432.CCR-06-0988

6. Piccinelli M, Wilkinson G. Gender differences in depression. Critical review. Br J Psychiatry 2000; 177: 486-92; http://dx.doi.org/10.1192/bjp.177.6.486

7. Franconi F, Brunelleschi S, Steardo L, et al. Gender differences in drug responses. Pharmacol Res 2007; 55: 81-95; http://dx.doi.org/10.1016/j.phrs.2006.11.001

8. Hafner H. Gender differences in schizophrenia. Psychoneuroendocrinology 2003; 28 Suppl 2: 1754; http://dx.doi.org/10.1016/S0306-4530(02)00125-7

9. Cheung WY, Le LW, Gagliese L. Age and gender differences in symptom intensity and symptom clusters among patients with metastatic cancer. Support Care Cancer 2011; 19: 417-23; http:// dx.doi.org/10.1007/s00520-010-0865-2

10. Carey RG, Posavac EJ. Holistic care in a cancer care center. Nurs Res 1979; 28: 213-6; http://dx.doi. org/10.1097/00006199-197907000-00007

11. Zimmermann C, Burman D, Swami N, et al. Determinants of quality of life in patients with advanced cancer. Support Care Cancer 2011; 19: 621-9; http://dx.doi.org/10.1007/s00520-010-0866-1

12. Sela RA, Bruera E, Conner-spady B, et al. Sensory and affective dimensions of advanced cancer pain. Psychooncology 2002; 11: 23-34; http://dx.doi.org/10.1002/pon.551

13. Zeng L, Koo K, Zhang L, et al. Fatigue in advanced cancer patients attending an outpatient palliative radiotherapy clinic as screened by the Edmonton Symptom Assessment System. Support Care Cancer 2012; 20: 1037-42; http://dx.doi.org/10.1007/s00520-011-1179-8

14. Zimmermann C, Burman D, Follwell M, et al. Predictors of symptom severity and response in patients with metastatic cancer. Am J Hosp Palliat Care 2010; 27: 175-181; http://dx.doi. org/10.1177/1049909109346307

15. Dunlop G. A Study of the Relative Frequency and Importance of Gastrointestinal Symptoms, and Weakness in Patients with Far Advanced Cancer: Student Paper. Palliative medicine 1989; 4: 37-43; http://dx.doi.org/10.1177/026921639000400108

16. Walsh D, Donnelly S, Rybicki L. The symptoms of advanced cancer: relationship to age, gender, and performance status in 1,000 patients. Support Care Cancer 2000; 8: 175-9; http://dx.doi. org/10.1007/s005200050281

17. Reuben DB, Mor V. Nausea and vomiting in terminal cancer patients. Arch Intern Med 1986; 146: 2021-3; http://dx.doi.org/10.1001/archinte.146.10.2021 
18. Mercadante S, Casuccio A, Fulfaro F. The course of symptom frequency and intensity in advanced cancer patients followed at home. J Pain Symptom Manage 2000; 20: 104-12; http://dx.doi. org/10.1016/S0885-3924(00)00160-3

19. Mercadante S, Fulfaro F, Casuccio A. The impact of home palliative care on symptoms in advanced cancer patients. Support Care Cancer 2000; 8: 307-10; http://dx.doi.org/10.1007/s005209900110

20. Komurcu S, Nelson KA, Walsh D, et al. Gastrointestinal symptoms among inpatients with advanced cancer. Am J Hosp Palliat Care 2002; 19: 351-5; http://dx.doi.org/10.1177/104990910201900513

21. Kanbayashi Y, Okamoto K, Ogaru T, et al. Statistical validation of the relationships of cancer pain relief with various factors using ordered logistic regression analysis. Clin J Pain 2009; 25: 65-72; http://dx.doi.org/10.1097/AJP.0b013e31817e1379

22. Mercadante S, Casuccio A, Pumo S, et al. Factors influencing the opioid response in advanced cancer patients with pain followed at home: the effects of age and gender. Support Care Cancer 2000; 8: 123-30; http://dx.doi.org/10.1007/s005200050026

23. Tu MS, Chiou CP. Perceptual consistency of pain and quality of life between hospice cancer patients and family caregivers: a pilot study. Int J Clin Pract 2007; 61: 1686-91; http://dx.doi.org/10.1111/ j.1742-1241.2007.01347.x

24. Heedman PA, Strang P. Symptom assessment in advanced palliative home care for cancer patients using the ESAS: clinical aspects. Anticancer Res 2001; 21: 4077-82

25. Mystakidou K, Tsilika E, Parpa E, et al. Self-efficacy beliefs and levels of anxiety in advanced cancer patients. Eur J Cancer Care (Engl) 2010; 19: 205-11; http://dx.doi.org/10.1111/j.13652354.2008.01039.x

26. Holzner B, Kemmler G, Cella D, et al. Normative data for functional assessment of cancer therapy - general scale and its use for the interpretation of quality of life scores in cancer survivors. Acta Oncol 2004; 43: 153-160; http://dx.doi.org/10.1080/02841860310023453

27. Pater JL, Zee B, Palmer M, et al. Fatigue in patients with cancer: results with National Cancer Institute of Canada Clinical Trials Group studies employing the EORTC QLQ-C30. Support Care Cancer 1997; 5: 410-3; http://dx.doi.org/10.1007/s005200050100

28. Kroenke K, Wood DR, Mangelsdorff AD, et al. Chronic fatigue in primary care. Prevalence, patient characteristics, and outcome. JAMA 1988; 260: 929-34; http://dx.doi.org/10.1001/jama.260.7.929

29. Husain AF, Stewart K, Arseneault R, et al. Women experience higher levels of fatigue than men at the end of life: a longitudinal home palliative care study. J Pain Symptom Manage 2007; 33: 389-97; http://dx.doi.org/10.1016/j.jpainsymman.2006.09.019

30. Akechi T, Kugaya A, Okamura $\mathrm{H}$, et al. Fatigue and its associated factors in ambulatory cancer patients: a preliminary study. J Pain Symptom Manage 1999; 17: 42-8; http://dx.doi.org/10.1016/ S0885-3924(98)00105-5

31. Pascoe S, Edelman S, Kidman A. Prevalence of psychological distress and use of support services by cancer patients at Sydney hospitals. Aust N Z J Psychiatry 2000; 34: 785-91; http://dx.doi. org/10.1080/j.1440-1614.2000.00817.x

32. Aass N, Fossa SD, Dahl AA, et al. Prevalence of anxiety and depression in cancer patients seen at the Norwegian Radium Hospital. Eur J Cancer 1997; 33: 1597-604; http://dx.doi.org/10.1016/ S0959-8049(97)00054-3

33. Linden W, Vodermaier A, Mackenzie R, et al. Anxiety and depression after cancer diagnosis: prevalence rates by cancer type, gender, and age. J Affect Disord 2012; 141: 343-51; http://dx.doi. org/10.1016/j.jad.2012.03.025

34. Keogh E, Bond FW, Hanmer R, et al. Comparing acceptance- and control-based coping instructions on the cold-pressor pain experiences of healthy men and women. European Journal of Pain 2005; 9: 591-8; http://dx.doi.org/10.1016/j.ejpain.2004.12.005 
35. Soetanto AL, Chung JW, Wong TK. Are there gender differences in pain perception? J Neurosci Nurs 2006; 38: 172-6; http://dx.doi.org/10.1097/01376517-200606000-00006

36. Fillingim RB, Maixner W. Gender differences in the responses to noxious stimuli. Pain Forum 1995; 4: 209-21

37. Rieker PP, Bird CE. Rethinking gender differences in health: why we need to integrate social and biological perspectives. J Gerontol B Psychol Sci Soc Sci 2005; 60: 40-7; http://dx.doi.org/10.1093/ geronb/60.Special_Issue_2.S40

38. Chavannes NH, Huibers MJ, Schermer TR, et al. Associations of depressive symptoms with gender, body mass index and dyspnea in primary care COPD patients. Fam Pract 2005; 22: 604-7; http://dx.doi.org/10.1093/fampra/cmi056

39. Chen W, Woods SL, Puntillo KA. Gender differences in symptoms associated with acute myocardial infarction: a review of the research. Heart Lung 2005; 34: 240-7; http://dx.doi.org/10.1016/j. hrtlng.2004.12.004

40. Chen W, Woods SL, Wilkie DJ, et al. Gender differences in symptom experiences of patients with acute coronary syndromes. J Pain Symptom Manage 2005; 30: 553-62; http://dx.doi.org/10.1016/j. jpainsymman.2005.06.004 